IRA-International Journal of Education \& Multidisciplinary Studies

ISSN 2455-2526; Vol.05, Issue 02 (2016)

Pg. no. 86-93

Institute of Research Advances

http://research-advances.org/index.php/IJEMS

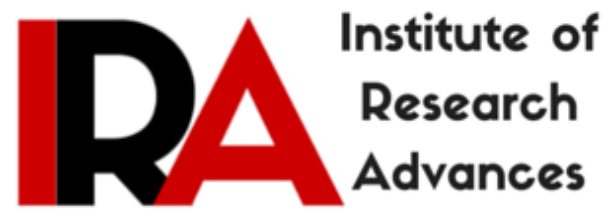

\title{
Memorizing Partition and Transmission of Trauma in Reema Moudgil's Perfect Eight
}

\section{Dr. Preetha Vasan}

Professor, Jyoti Nivas College,

Post Graduate Centre, Bangalore, India.

Type of Review: Peer Reviewed.

DOI: http://dx.doi.org/10.21013/jems.v5.n2.p4

\section{How to cite this paper:}

Vasan, P. (2016). Memorizing Partition and Transmission of Trauma in Reema Moudgil's Perfect Eight. IRA International Journal of Education and Multidisciplinary Studies (ISSN 2455-2526), 5(2), 86-93. doi:http://dx.doi.org/10.21013/jems.v5.n2.p4

(C) Institute of Research Advances

\section{(c)) EY-NO}

This work is licensed under a Creative Commons Attribution-Non Commercial 4.0 International License subject to proper citation to the publication source of the work.

Disclaimer: The scholarly papers as reviewed and published by the Institute of Research Advances (IRA) are the views and opinions of their respective authors and are not the views or opinions of the IRA. The IRA disclaims of any harm or loss caused due to the published content to any party. 


\begin{abstract}
Literary studies and historiographies have restored and recovered a number of Partition narratives. This paper interrogates the revisiting of partition memory in Reema Moudgil Perfect Eight which returns to partition memory, through two generations. It compares the trajectories of this memory for a first generation survivor with the intergenerational memory of the daughter who vicariously relives this past.
\end{abstract}

Partition riots and the consequential physical and psychological violence was a singular debacle in our nation's history, accentuated further by the paradoxical fact that it came along with the much awaited dawn of freedom. The creation of the two nations - India and Pakistan, after centuries of colonial rule, was marked in the North West frontiers and in the Bengal by ineffable chaos, gore and human being's bestiality to fellow humans. Millions of people left their homes, lands and sometimes families to cross over to the other side to escape savage mobs that would resort to rape, arson, and genocidal violence. Mainstream nationalist historiography with its focus on nation building, and forging a common shared community has obfuscated this complex historiography. Nationalist accounts have privileged their particular centres validating their versions, thus peripheralising some and delegitimizing others' point of view. However literary writings on the partition have recovered stories, testimonies and accounts hitherto suppressed by official historiography.

From 1947 to the present, the trauma of partition has caused several revisiting by historians, writers, culture critics and film makers. First generation Partition writers like Sadat Hassan Manto, Faiz Ahmed Faiz, and Khushwant Singh bemoan the disillusionment and dystopia that replaced their utopian imaginaries. Writing within the immediate context of the violence they note the carnage with a dark irony and horror. Second generation writers like Bhisham Sahni and others revisit partition to understand and analyse the continuum of the partition madness in other forms of communal violence and contemporary traumas. All these writers of partition grapple with the question, whether there is an appropriate way to carry out the reproduction and remembering of the partition .Certainly, in our postcolonial world it has become the central, immense event of the last century, which has been riveted into a "code" of instantly recognisable pictures and texts. The fixed memories of partition are repeatedly memorialised in literary and non-literary texts. Our memory of the partition dominates our public and private consciousness to such an extent that this memory is actively remembered during any new catastrophe, where hate dynamics crystallise and demonise the other group. The paper attempts to analyse the ensuing collective and individual trauma a person undergoes when an intergenerational memory of partition is handed down from a first generation survivor of the partition. The internalisation of such a traumatic memory results in the internalisation of a fracturing of self and subsequent loss of identity. The paper also reviews the possible need to revisit this cultural historical memory of a collective, albeit vicariously, for the nation to understand its turbulent present.

Holocaust literary critic and scholar, James Young and Marianne Hirsch attempt to understand similar traumatic memories in the works of Holocaust writers and artists. Young in his study of second generation Shoah memorials , denotes a "vicarious past", derived from a "'received history", in the absence of first-hand knowledge of the events themselves: . He notes that for many members of the second generation it is hard to "remember" the Shoah outside of the ways it was passed on to them fifty years later (Young, 669).In a similar argument cultural memory theorist, Marianne Hirsch posits the concept of "postmemory", wherein, postmemory is distinguished from memory by generational distance and from history by deep personal connection. Yet she notes how this is "a powerful and very particular form of memory precisely because its connection to its object or source is mediated, not through recollection but through an imaginative investment and creation". Postmemory, Hirsch insists, is not "absent memory", or the "gaping black hole of the unmentionable years" but it characterises the experience of those who grow up dominated by narratives that preceded their birth, whose own belated stories are evacuated by the stories of the previous generation shaped by traumatic events that can be neither understood nor recreated' (Hirsch, 21-22). 
A former journalist and Radio Jockey, Reema Moudgil is the author of Perfect Eight and the Executive Editor of the online website, Unboxed Writers. Perfect Eight narrated by an unnamed first person, who later is identified as Ira, moves from Lahore to Kanpur to an Assamese cantonmentto Patiala to Ambrosa to Bangalore. Through these spatial shifts it also takes us through communal riotsproving that what commenced with Partition continues to play it out in the multiple ethnic conflicts that ravage the postcolonial nation.

In Perfect Eight "Ma" Ira's mother's trauma of partition, with which the novel begins, is remembered in the first person account of Ira. Interestingly "Ma" never acquires a name till the end on the one hand symbolising the countless, nameless hapless victims of partition and on the other to possibly suggest the irrecoverable loss of her identity. Chapters three and four of Perfect Eight, powerfully recount this loss of Ma to the unnameable terror and carnage of the partition. Ira's mother's history of pain had started in Lahore, then a part of undivided India, when she was just five. The only child of an affluent father who got his fur-collared overcoats tailored in London and a mother who was one of the most beautiful women in Lahore, she herself had lived in opulence and, with a rich inheritance. The narration of mother's story is done by the adult Ira but the focalizer in these accounts is the unperceiving "Ma". This captures the trauma of "Ma" in complex ways. The juxtapositioning of the uncomprehending "Ma", who in this decisive flashback is five years old, with our comprehension of the cataclysm that unfurls uncontrollably in the background, facilitates the reader's understanding of mother's post traumatic stress disorder and the fragmented identity of Ira, the inheritor of this trauma and memory. As Lahore burns, like Lenny in Ice-Candy-Man, Ma too notices the solidifying of religious identities when friends stop dropping home, when the Hindu and Muslim poets stop sitting together to say "wah wah" to each other and finally the Muslim chaperone, Abdul also stops coming. "The invisible lines dividing the neighbourhood became charcoal dark and then red "( Perfect Eight ${ }_{2}$ 15)With Pakistan "hewn" out of India and as Lahore goes up in the flames of communal violence Ma's father refuses to uproot himself because he was a Hindu. One day while playing in the backyard Ma's parents are destroyed with their ancestral home. Laurie Vickroy comments that trauma narratives go beyond presenting trauma as subject matter or character study. By “ internalizing the rhythms, processes and uncertainties"(Vickroy, 3) of Ma's traumatic experience, the narrative through its structure reveals many obstacles to communicating such experience .Some of these which Vickroy notes are also true of the narration of Ma's ordeal. As Ira's mother watches uncomprehendingly her ancestral home with her parents in it burnt down, hears, what she thinks are lazy crackers and finally smells burnt walls and cold blood she has "a simultaneous knowledge and denial of her experience"( Vickroy, 3). She "disassociates, represses and resists" (Vickroy, 3) this loss in years to come which alienate her from her sense of self. As she stumbles into a neighbouring Muslim house, she is bundled in a quilt and hidden in a dark room from the hate filled eyes of the Muslims. It is from this moment, mother's trauma leads to her fragmented sense of self. Thus Ira's mother, as a five year old, along with Tai, a Hindu cleaning woman "walked out of a history that was no longer theirs" (Perfect Eight 16). The long journey from Kanpur to Lahore for the five year old is a traumatizing one filled with pain and suffering. Memories, during this journey she realises "could be put in carts and whistled off with their bleeding roots to unfamiliar soils" (Perfect Eight, 17).

Cathy Caruth states that to be traumatized is to be possessed by an image or an event. These memories and the ensuing fear seal the crumbling contours of Ma's inner self, possessing her for the rest of her life. Later in life she would transmit these harrowing memories to her daughter who would carry the painful burden of the unseen pain and suffering of her mother through her life. The memories of her journey towards an uncertain future also teach Ma strange lessons in life's swinging scales of joy and sorrow. It teaches her that human beings even with "beribboned inheritances" could be annihilated overnight. As she walks for weeks, she could see "death burning quietly" (Perfect Eight 17), fear in its inexorable flight over the refugees as they edged their way towards an unknown land, men and women shivering "outside the broken shells of their lives" (Perfect Eight 17). The smell of cold burning flesh becomes an inseparable part of the long journey and her life .Ma carries with her this "impossible history" (Caruth, 3) and sometimes becomes the symptoms of this history she cannot possess. The little girl's journey ends only in a traumatic life in Kanpur. Her new home turns a cold shoulder, an impersonal unresponsiveness to her pain and grief. Ma's fragmentation 
further disintegrates in the cold apathy of the Kanpur house, the house of her father's childhood friend. Ma never does fully assimilate the traumatic events of partition. Hence experiences it "belatedly, in its repeated possession of the one who experiences it" (Caruth, 4). Ma's uncertainty is "certainly not amnesia but the return of the event insistently against her will" (Caruth, 4). Caruth also recognises that faithfulness to the dead is a common burden of traumatized survivors. This particularly evident in the dream Ma has of her parents and her inability to touch toys that had not been bought for her. It is this repeated possession of the memory of partition and the greater loss of her parents that leads Ma to "embrace more injuries, jumping again and again, from other windows and other ledges. Denying herself the choice to hold on to life's promises" (Perfect Eight, 11).

As history unfolds relentlessly around Ma, with India celebrating her freedom and a year later Gandhi being assassinated by Naturam Ghotse, Ma's private trauma follows her unresolved. Whether it is being blamed for Gandhi's assassination in, "...throw that refugee bitch outside. One of her kind must have shed Bapu's blood" (Perfect Eight, 20) or her taunting mother-in -law's comment "I don't like rifoojis. They spread misfortune wherever they go" (Perfect Eight, 26), Ma is constantly classified as the refugee, the outsider and the rootless one. Her absolute loss of her sense of self is complete when she enters her husband's home. However Ma revives albeit temporarily with the unconditional love of her husband but the final resurgence to abandon her desire for death comes on the decisive night when she feels Ira stir in her womb, just when she is about to jump off the bed. But while "life began to seep back into her bones...the pain does not seep out" and the trauma passes on unassimilated to Ira. Caruth observes the difference between trauma inflicted upon the body and trauma upon the mind and notes that while "wound on the body is simple and healable; the wound on the mind is experienced too soon too unexpectedly to be fully known" (3). It is trauma on the mind that Ma passes on to Ira, imposing itself again repeatedly in the nightmares that haunt Ira- the victim of a traumatic postmemory of the partition. Ma's inner wanderings and displacements are now passed on to Ira, and the former's haunting reminders of dead memories are now unconsciously and repetitively relived by the latter.

Marianne Hirsch defines postmemory as "the relationship of the second generation to powerful, often traumatic experiences that preceded their births but that were nevertheless transmitted to them so deeply as to seem to constitute memories in their own right"( 104). Ira in_Perfect Eight is the "the second generation" or the "hinge generation" in which received transferred knowledge of the partition is being "transmuted into history, or into myth" (Eva Hoffman, qtd in Hirsch, 104). Ira is given "guardianship" (Hirsch, 104) of a traumatic "personal and generational past" (ibid) with which she has a "living connection" (ibid) owing to her mother. Quoting Assmann, Hirsch differentiates between two kinds of collective remembrance- communicative memory and cultural memory (110). The former is "biographical and factual" and is located "within a generation of contemporaries who witness an event and pass on their bodily and affective connections of that memory to the next generation", hence it is "intergenerational" (Hirsch, 110). However it becomes necessary to "institutionalize this memory as an archival memory" so that it is "transgenerational" (110). Such a memory constitutes a national, political memory, what Assmann calls "cultural memory" .Intergenerational and cultural memories are kept distinct in Perfect Eight

In Perfect Eight together with the ownership of a generational past, the workings of the traumatic memory are passed on in this "intergenerational act of transfer" (Hirsch, 104) from Ma to Ira. Ira's personal story from the very beginning becomes a way of carrying forward her mother's story by appropriating her trauma and memory of partition .Ira's particular relation to her parental past described, analysed and evoked in the novel can be seen as a "syndrome of belatedness or postness and can be variedly termed as "absent memory, inherited memory, belated memory prosthetic memory, vicarious witnessing, received history or postmemory"( Hirsch,105).These terms reveal a number of contentious suppositions: that descendants of survivors ( of victims as well as perpetrators) of colossal harrowing events connect so deeply to the previous generation's recollections of the past, that they need to call that connection memory and thus in Ira's case, her mother's memory is transmitted to her who in fact was not there to live the event. Ira's is a received memory, perhaps the text suggests, narrated to her by her mother hence it is distinct from her mother's (who was a 
contemporary witness and participant) memory. Consequently it is important to stress on the "post" ness of Ira's memory though paradoxically this defines both "a specifically inter-and transgenerational act of transfer and the resonant after-effects of trauma" (Hirsch, 106).

Ira's postmemory makes her "look backward rather than ahead and defines the past in relation to troubled past rather than initiating new paradigms" (Hirsch, 106). Ira's postmemory is a consequence of her mother's traumatic recall of her past and experiences her mother's post traumatic stress disorder at a generational remove. The "paradox of indirect knowledge haunt many of us who came after" (Hoffman qtd in Hirsch, 106). This paradox of indirect knowledge haunts Ira in complex ways. Ira's mother's stories and experiences are transmitted so powerfully and affectively to Ira that they seem to constitute memories in their own right. Ira's post-memorial connection to her mother's past is thus not actually mediated by recall but by "imaginative investment, projection and creation" ( Hirsch,107).Growing up with these overwhelming inherited memories and narratives that preceded Ira's birth and consciousness, leads to Ira's experiences being displaced and evacuated in Ira's psyche by her mother's complex losses. Hence Ira's sense of self is shaped by traumatic events that defy narrative reconstruction and exceed comprehension. As she tells us "... my dysfunction was ... gene-deep. What a mess it all was. And all because Ma had jumped from a second-floor window when she was six" (Perfect Eight, 10) Partition happened in the past but their effects continue into the present.

Hirsch states that "postmemory is not identical to memory: it is 'post' but at the same time it approximates memory in its affective force" (109). It is to suggest this complexly burdened postmemory that informs Ira's sense of self that Ira's narration, especially of her mother's past, achieves what Vickroy suggests of the structure of narrations of trauma survivors. Ira's narration like "survivor's experience resists chronological narration or normal modes of artistic representation" (Vickroy, 5).Ira and her mother live in "durational rather than in chronological time" (ibid). Ira's present ,owing to her burdened inheritance from her mother, cannot experience the past as differentiated from the present ,but continues to " experience the horrors of the past as indistinct from the present"( Vickroy,5).

Perfect Eight in many ways records how the multiple ruptures and radical breaks introduced by trauma inflects "intra-inter and trans-generational inheritance" (Hirsch, 111).Laurie Vickroy proposes "the mother/daughter relation as an important locus of identity formation and perpetuation of traumatic identities" (10) in contemporary trauma narratives. Thus when Perfect Eight 's unnamed narrator begins her narration we can see the indelible effect on the narrator's psyche of a traumatic experience that has changed her nature of self-recognition, memory and relational life. The tyranny of her mother's past (as we come to know later) taints all her other experiences, spoiling her appreciation of the present. As a vicarious witness of her mother's past, by concentrating on the inheritance of her multiple losses, Ira tells us that she "learnt from her (her mother) to smell grief before it struck" (Perfect Eight, 3). With brooding foreboding she anticipates the rain washing away the school's Big Fete (ibid, 3), her mother's miscarriage (ibid, 34) and firmly believes that "....Happiness was something we would always leave behind and go somewhere else" (ibid, 5).

Fundamental to Ira's individual trauma is that past lingers unresolved, as her mother has not remembered it in a conventional sense, what Vickroy determines "as that which is not processed cognitively or emotionally" (12). In her mother's life where unhappiness and misfortunes seem to form a constellation of her experience, Ira inherits wariness as if life was a prolonged exposure to danger, constantly on the lookout for any sudden flash of terror. Symptomatic of Ira's trauma early on in the novel is her restlessness and her periods of nervous activity, when she could "never let beautiful things be" (Perfect Eight, 4). In her childhood, she scans the world around for signs of unhappiness like the announcements she makes about the jawan who dies of a tapeworm in the officer's mess or the puncturing of the mother of the "drooling birthday girl's" (Perfect Eight 4) happiness by baring details of the vulnerable skin of Mrs Vasanth- burnt in a fire accident (Perfect Eight_3-4).In her later years, especially in her adolescence in her fight to preserve her sense of self this becomes her attempts to insulate herself from further harm. 
Collective memory of partition unfurls as different separatist movements and terrorism in the post independent state in_Perfect Eight.As Ira grows up to be a teenager, terrorist attacks in Punjab and other parts of India grow bloodier by the day. In Patiala, in Ira's neighbourhood as in other parts of Punjab, in a mirror image of the partition Hindus and Sikhs who knew no differences suddenly turn against each other with hatred. Bhinderwale, whom Papu imagines is no threat, tries to convince the Hindus and Sikhs that they did not belong together. With Operation Blue Star that led to the storming of the Golden Temple to flush out terrorists, violence and counter violence now unfolds. With the Indian prime minister shot dead by her Sikh body guards, Sikhs are the persecuted minority in the anti-Sikh carnage that engulfs the country. Moudgil juxtaposes the shifting minority -majority locations when she shows Ira a Hindu in a Sikh dominated Patiala persecuted as a minority. In a postmemory recollection of partition violence the mass killings of the Sikhs and Hindus fills the air with hatred, fear and suspicion where once peace and tranquillity had reigned, neighbours turn against neighbours as is evident. Identities that had remained fluid concretise in the postcolonial state. The simmering violence in Ayodhya which reaches its climax in the demolition of the Babri Masjid at the end of the novel spreads to Bangalore where Ira settles down after her marriage. The assault on Ira by the conductor of a bus she is travelling in, in the presence of cold and indifferent fellow-passengers brings to her mind her mother's journey from Lahore towards the Indian border. The mindless attack on a movie theatre, rekindles her postmemory of the age old violence.

Healing and recovery from trauma and divisive memories at a personal and collective level are central to Perfect Eight. In Perfect Eight a central site and locale for such healings for mother and Ira is at the intersection of individuals and places- Anna aunty, Samir and Annaville. Anna aunty and Annaville are the novel's alternate worlds of happiness, fortune and sunshine. Anna aunty is in some ways mother's alter-ego, having everything she always wished for. Be it sudden blossoms , sunny days ,stars on a rainy night or her husband who names his opulent ancestral plantation after her, Anna aunty is mother's binary for she asks life for happiness and receives it in armfuls. To highlight this polarity Ira recounts her mother's wedding where everything goes wrong - the food, the ice-cream or the professional wedding mare replaced, almost disastrously by the mare used in police parade for riot control. If mother recovers from her trauma by trapping little gardens of sunlight and $\mathrm{b} y$ basking in the warmth of Anna's sisterhood and Papu's love, Ira turns to Anna's son Samir for a similar recovery. Ira believes throughout her narrative that Samir and she are severed halves, like her name wedged out of his name. Her quest for recovery and completion she deems would attain its end in her union with him to form like the road that loops through the tea gardens to Annaville, which Anna calls "Perfect Eight". Ira supposes she and Samir are "the two perfect halves running into each other" ( Perfect Eight ,53).But this " creating of self-concepts and thereby recovering a sense of self and agency in the face of devastating losses"( Vickroy, 9) does not work for Ira.

Ira attempts to desist her fragmentation, and the consequent profound disturbance of self through this relationship. But this attempt to create or maintain a sense of agency and order through her reaching out to Samir turns on its head leading to further loss of self. At different points in the novel this collapse of relationship leading to Ira's further disintegration is indicated whether in the way Samir makes Ira self-conscious of her poverty when he visits her in Patiala or the way Samir and Anu, Manna aunty( Anna's sister)'s daughter marginalise Ira during one of Ira's visit to Annaville.

But Ira though crushed initially, recovers .Her "ego strength" (Vickroy, 24) also develops from positive relations with her parents. "Dynamic relationships", states Vickroy, "should provide both safety and independent recognition ...making it possible for him or her to ... respond to the environment and discover him or herself within a cultural framework" (Vickroy, 24). This dynamic relationship that Ira shares with her parents is facilitated by mother's accident after which "... Papu became aware of Ma in a way he had never been ..." (Perfect Eight, 92). For Papu who had always been a loving husband conscious of mother's pain the many invisible hidden traumas of mother now become visible when " she had been X-rayed, blown up and plastered on the world's walls"(_Perfect Eight_93).Memories of partition return to mother when she is recovering from her accident . But Papu protects her and helps in mother's multiple healing. This "dynamic relationship" is what enables Ira to retrieve and retain her strong sense of self even when Samir rejects her open declaration of her love (Perfect Eight 146). But the post-memorial apprehension of happiness comes fatally true when 
exactly “ four months after" Ira's "memory filled birthday" Papu's colleague calls to announce Papu's death of a " massive heart attack"( Perfect Eight, 117)

Trauma returns to haunt Ira through this loss, later her futile marriage to Gautam and her sterile life amongst his facile colleagues and his flirtatious boss, Sarita in Bangalore. Still shaped by her mother's traumatic past, when her marriage to Gautam turns out to be a failure, Ira attempts suicide. Gautam who always believed that he did the right thing never hurt her but takes away her "sense of living" (Perfect Eight, 210). Desiring but denied the simple pleasures like, "To look at the sunset and smile. Watch the moon when it sheds its silver shadows on the road without feeling sad" (Perfect Eight, 210); Ira resorts to a forgotten trans generational memory- suicide. However the same memory, of her mother also fills Ira with a strong desire to live, "for the little girl who had walked endless miles to grow up and bring another life into the world" (Perfect Eight, 206).

Vickroy locates in traumatised subject "dialogism of detachment and emotion" (28).Her postmemory fosters both Ira's lonely desires (as evidenced earlier) and distrust in intimacy for Samir. These shifts become evident in her final journey to Annaville to visit Anna aunty, where she would inevitably see Samir (now engaged to be married to an unknown Navya) and who is also ready to change Annaville into a resort. However despite the fulfilment of the long sought after union with Samir, suggested in the sexual coming together ,acquiring symbolic significance when Ira's name is for the first time mentioned in the narrative, uttered here by Samir, Ira rejects this what she sees, as acknowledgement by Samir. As Yeshoda Nanjappa points out, "She soon realizes that Samir like Gautam can never love anyone. Samir did not have roots anywhere and felt unsettled where ever he went though he carried no burdens like she did" (77).Ira's rejection of Samir, to add to Nanjappa's observation is in complex ways facilitated by the variegated bundle of her memories and postmemories- her mother's life ripped apart in Lahore, her poverty in Patiala, the pain of her father's death, her self-defense against perverts and finally her marriage (Perfect Eight, 250). Burdened by these complex pasts she chooses legitimacy in this painful memory and disallows the memory of the night Samir had given her. The rejection of this memory is itself a final rejection of victimhood. For as she tells us "I saw Samir taking my life and putting it in a jam bottle he would never open" (ibid), so she turns down a recollection that Samir wants her to remember to validate his sense of self. She denies him this memory, discounting it for precious others that may have caused pain but had nevertheless authenticated her existence. With this denial Ira's recovery begins. While Perfect Eight resolves the personal trauma of Ira, it leaves the larger cultural memory of partition unresolved,

\section{References}

Moudgil, Reema. Perfect Eight. Chennai: Tranquebar, 2010.

Assmann Aleida "Memory, Individual and Collective" The Oxford Handbooks of Political Science. Ed Robert .E. Goodin. Oxford: OUP, 2006

Assmann, Jan and John Czaplicka "Collective Memory and Cultural Identity". New German Critique 65(1995) 125-133

Brewer, John.D. "Memory, Truth and Victimhood in Post-trauma Societies"The Sage Handbook of Nations and Nationalism. Ed Gerard Delanty and Krishan Kumar London: Sage, 2006.

Craps, Stef and Michael Rothberg "Introduction: Transcultural Negotiations of Holocaust Memory" Criticism53.4 (2011) 517-521

Hirsch, Marianne “The Generation of Postmemory” Poetics Today 29.1(2008)104-128

Hofmann, Eva "After such Knowledge" qtd in Marianne Hirsch "The Generation of Postmemory" Poetics Today 29.1(2008)104-128

Saint .K. Tarun Witnessing Partition New Delhi: Routledge, 2010 
Schwab, Gabriel "Introduction" Haunting Legacies: Violent Histories and Transgenerational Trauma New York: Columbia University Press, 2010

Vickroy, Laurie "Representing Trauma: Issues, Contexts, Narrative Tools" Trauma and Survival in Contemporary Fiction. Charlottesville: University of Virginia Press, 2002.

Young, .E. James "The Holocaust as Vicarious Past: Art Spiegelman's Maus and the Afterimage of History." Critical Enquiry 24.3(1998) 666-699. 